\title{
The efficacy of an endocervical brush in obtaining adequate Papanicolaou smears
}

\author{
MICHAEL B. GROSSMAN, DO \\ RICHARD CLOFINE, DO
}

A total of 249 consecutive women attending a family planning clinic were entered in a study to determine the efficacy of the endocervical brush versus the cotton swab in obtaining routine $\mathrm{Pa}$ panicolaou smears. Also investigated were whether the experience level of the smear taker contributed to the adequacy of the sample and whether simultaneous sampling by means of the spatula (an ectocervical sampling method) was justified. The use of the endocervical brush in place of the swab was found to improve cell collection by reducing the frequency of inadequate smears. The experience of the sample taker appeared not to be a factor in obtaining adequate smears. In $9 \%$ of the samples, only the ectocervical specimen was found to be satisfactory, indicating that use of the spatula should not be abandoned.

(Key words: Papanicolaou smear, endocervical brush, cervical cytology)

The efficacy of the endocervical brush in obtaining quality Papanicolaou smears has been suggested in the literature. ${ }^{1-8}$ Assuming the

From the University of Medicine and Dentistry of New Jersey-School of Osteopathic Medicine and Kennedy Memorial Hospitals-University Medical Center, Stratford, where Dr Grossman is professor of obstetrics and gynecology and where, at the time this article was written, Dr Clofine was a resident. Dr Clofine currently is in private practice in Tucker, Ga.

Reprint requests to Michael B. Grossman, D.O., 301 South Central Plaza, Suite 2500, Stratford, NJ 08084. improved quality of the smear, as evidenced by better sampling of the squamocolumnar junction and transformation zone, the endocervical brush should replace the cotton swab for endocervical sampling in clinical practice. There is some debate regarding whether variations in Papanicolaou smear adequacy may be related to the experience of the sample taker ${ }^{3,4,9}$ as well as to the phase of the patient's menstrual cycle at the time of sampling and the method of contraception used by the patient. ${ }^{10}$

A pilot study was undertaken to affirm the greater efficacy of the endocervical brush versus the cotton swab in collecting cells for the Papanicolaou smear in our suburban teaching clinic. This study also investigated whether the skill level of the individual obtaining the smear influenced the adequacy of the sample, whether taken by brush or by cotton swab. The contribution of the spatula (an ectocervical sampling method) to Papanicolaou smear efficacy was also investigated. The two skill groups obtaining smears were composed of residents in the obstetrics and gynecology program (higher skill level) and third-year medical students (lower skill level).

\section{Materials and methods}

A total of 249 women were seen from June 1, 1988 to August 31, 1988 in the Ambulatory Care Center, a clinic of the University of Medicine and Dentistry of New Jersey-School of Osteopathic Medicine. This is a teaching clinic that involves thirdyear medical students in patient care. It represents one of their first clinical experiences in medical 


\begin{tabular}{|c|c|c|c|c|}
\hline \multicolumn{5}{|c|}{$\begin{array}{l}\text { Table } 1 \\
\text { Adequacy of Papanicolaou Smears Taken by Endocervical Brush } \\
\text { and by Cotton Swab-Residents Versus Students }\end{array}$} \\
\hline \multirow[b]{2}{*}{$\begin{array}{l}\text { Usuable smears } \\
\qquad(n=240)\end{array}$} & \multicolumn{2}{|c|}{$\begin{array}{l}\text { Residents } \\
(\mathbf{n}=158)\end{array}$} & \multicolumn{2}{|c|}{$\begin{array}{l}\text { Students } \\
(\mathrm{n}=\mathbf{8 2})\end{array}$} \\
\hline & No. & $\%$ & No. & $\%$ \\
\hline $\begin{array}{l}\text { Adequate } \\
\text { Total }\end{array}$ & 135 & 85 & 71 & 87 \\
\hline By endocervical brush & 79 & 96 & 48 & 96 \\
\hline By cotton swab & 56 & 74 & 23 & 72 \\
\hline $\begin{array}{l}\text { Inadequate } \\
\text { Total }\end{array}$ & 23 & 15 & 11 & 13 \\
\hline By endocervical brush & 3 & 4 & 2 & 4 \\
\hline By cotton swab & 20 & 26 & $\overline{9}$ & 28 \\
\hline
\end{tabular}

school. The clinic is run by the gynecology residents under the on-site supervision of an attending physician. The previous training in pelvic examination for these students was a single supervised examination of surrogate patients in the second year of medical school. As third-year students, they were instructed in the proper method of obtaining a Papanicolaou smear; they carried out the procedure under close ("hands-off") supervision.

The primary setting for obtaining a Papanicolaou smear was a family planning visit. None of the patients in this setting were being reevaluated for previous abnormal smears. The endocervical samples were first obtained from each patient by means of two different sampling devices: a cotton swab and a cervical brush (Zelsmyr Cell Collector, International Cytobrush, Inc). Then, a sample was obtained from each patient by means of a wooden spatula. Endocervical and ectocervical specimens were placed on separately marked slides and sprayed immediately with standard spray fixative. The slides were read by members of the cytology department at the university hospital under the supervision of the pathologist. The pathology department was blinded as to the method used and the practitioner taking the sample.

Slides were considered satisfactory if one of two criteria were met: the presence of endocervical cells or the presence of squamous cell metaplasia. Either was considered evidence that the squamocolumnar junction or transformation zone had been sampled. All samples were evaluated according to (1) the adequacy of the smear; (2) whether it had been obtained by a resident or a student; and (3) whether it had been obtained by endocervical brush or swab. Subsequently, the data were evaluated again to see which sample (endocervical or ectocervical) contributed to the adequacy of the smear.

\section{Results}

A total of 249 smears were obtained and, of these, 240 were usable for the first portion of the study, which evaluated resident versus student and brush versus swab (Table 1 ). Nine smears were unusable because of mislabeling or breakage in transport. Of the usable smears, $158(66 \%)$ were obtained by residents and 82 (34\%) were obtained by students. Of all smears obtained by residents, $135(85 \%)$ were satisfactory and $23(15 \%)$ were unsatisfactory. The students obtained $71(87 \%)$ satisfactory samples and $11(13 \%)$ that were unsatisfactory.

Of the smears with endocervical samples obtained by brush, the residents obtained 79 (96\%) satisfactory samples and $3(4 \%)$ that were unsatisfactory. The students similarly had $48(96 \%)$ satisfactory samples and $2(4 \%)$ that were unsatisfactory. When cotton swabs were used for the endocervical specimen, residents' results were $56(74 \%)$ satisfactory and $20(26 \%)$ unsatisfactory. Students' results were $23(72 \%)$ satisfactory and $9(28 \%)$ unsatisfactory. The difference between students' and residents' sampling was insignificant.

The data were then evaluated to determine the endocervical and ectocervical contributions 


\begin{tabular}{|c|c|c|c|}
\hline \multicolumn{4}{|c|}{$\begin{array}{c}\text { Table } 2 \\
\text { Ectocervical (Spatula-Obtained) and Endocervical Contributions } \\
\text { to Adequacy of Usable Papanicolaou Smears }(n=215) \text { Obtained by } \\
\text { Endocervical Brush }(n=126) \text { and Cotton Swab }(n=89)\end{array}$} \\
\hline Contribution to adequacy & No. & $\%$ & Comment \\
\hline $\begin{array}{l}\text { - Satisfactory ectocervical } \\
\text { sample } \\
\text { With satisfactory endo- } \\
\text { cervical sample }\end{array}$ & 132 & 61 & Best smear \\
\hline $\begin{array}{l}\text { With unsatisfactory } \\
\text { endocervical sample }\end{array}$ & 20 & 9 & Spatula saves \\
\hline $\begin{array}{l}\text { Unsatisfactory ectocervica } \\
\text { sample } \\
\text { With satisfactory endo- } \\
\text { cervical sample }\end{array}$ & 32 & 15 & Brush/swab saves \\
\hline $\begin{array}{l}\text { With unsatisfactory } \\
\text { endocervical sample }\end{array}$ & 31 & 14 & $\begin{array}{l}\text { Unsatisfactory by } \\
\text { either method }\end{array}$ \\
\hline
\end{tabular}

to the adequacy of the smear (Table 2). Of the 249 patients sampled, 215 smears were usable for this portion of the study. Thirty-four specimens were not usable because of mislabeling, no labeling, or breakage in transport. The data from both residents and students were evaluated as a single group. Of the 215 usable smears, $126(59 \%)$ were obtained with the brush and $89(41 \%)$ were swab specimens.

Four groups of smears were available for evaluation. The first group comprised those that were satisfactory (according to the previously described criteria) for both the endocervical (brush or swab) and the ectocervical (spatula) slides. The second group met the criteria only on the basis of the endocervical specimen. The third group met the criteria only because of the ectocervical specimen. The fourth group was considered unsatisfactory because neither the endocervical nor the ectocervical smears met the criteria. These four groups were then evaluated after the endocervical brush and swab samples were assessed separately (Table 3 ).

Of the 215 smears available for evaluation, $132(61 \%)$ had both satisfactory ectocervical and satisfactory endocervical slides. Of the 126 smears with brush-obtained endocervical slides, $96(76 \%)$ had both satisfactory ectocervical and satisfactory endocervical slides. In the 89 smears using the cotton swab, 36
(40\%) had satisfactory endocervical and ectocervical specimens.

Thirty-two (15\%) of the 215 smears available for evaluation had satisfactory endocervical specimens only, with the spatula specimen not meeting adequacy criteria. Of all smears for which the brush was used for endocervical sampling, $23(18 \%)$ had satisfactory endocervical smears only. This was the case with $9(10 \%)$ of all smears taken with cotton swabs.

Of all 215 smears in the study, only $20(9 \%)$ were satisfactory solely because of the contribution of the ectocervical (spatula-obtained) slide. Of those smears in which the brush was used to obtain endocervical specimens, only 2 (2\%) of the smears were made adequate by the use of the spatula; whereas in the swab-obtained group, $18(20 \%)$ of the smears were saved by the spatula. Of the 215 smears, 31 (14\%) were unsatisfactory by either ectocervical or endocervical techniques. Of all smears obtained with the brush, only $5(4 \%)$ were totally unsatisfactory. Of all smears obtained with the cotton swab, $26(29 \%)$ were unsatisfactory.

\section{Discussion}

Many researchers have evaluated the efficacy of a brush in obtaining endocervical smears. The data from various centers have been uni- 


\begin{tabular}{|c|c|c|c|c|}
\hline \multicolumn{5}{|c|}{$\begin{array}{c}\text { Table } 3 \\
\text { Evaluation of Endocervical Papanicolaou Smears } \\
\text { Obtained by Endocervical Brush and Cotton Swab and } \\
\text { Ectocervical Smears Obtained by Wooden Spatula }\end{array}$} \\
\hline \multirow[b]{2}{*}{ Adequacy } & \multicolumn{2}{|c|}{$\begin{array}{c}\text { Endocervical } \\
\text { brush } \\
(\mathrm{n}=126,59 \%)\end{array}$} & \multicolumn{2}{|c|}{$\begin{array}{c}\text { Cotton } \\
\text { swab } \\
(n=89,41 \%)\end{array}$} \\
\hline & No. & $\%$ & No. & $\%$ \\
\hline $\begin{array}{l}\text { - Satisfactory ectocervi } \\
\text { sample } \\
\text { With satisfactory endo- } \\
\text { cervical sample }\end{array}$ & 96 & 76 & 36 & 40 \\
\hline $\begin{array}{l}\text { With unsatisfactory } \\
\text { endocervical sample }\end{array}$ & 2 & 2 & 18 & 20 \\
\hline $\begin{array}{l}\text { - Unsatisfactory ectocer } \\
\text { sample } \\
\text { With satisfactory endo- } \\
\text { cervical sample }\end{array}$ & 23 & 18 & 9 & 10 \\
\hline $\begin{array}{l}\text { With unsatisfactory } \\
\text { endocervical sample }\end{array}$ & 5 & 4 & 26 & 29 \\
\hline
\end{tabular}

versally favorable regarding the increased efficacy of the endocervical brush in obtaining a quality endocervical specimen when compared with the cotton swab. ${ }^{1-7}$

Although most centers agree that recovery of columnar endocervical cells is necessary for a technically adequate Papanicolaou smear, ${ }^{2,3,11}$ there is still some controversy regarding what criteria should be used to define an "adequate" smear. ${ }^{12}$ For the purpose of this study, evidence of sampling of either the squamocolumnar junction or transformation zone constituted satisfactory smear.

Many factors affect the incidence of cervical smears lacking endocervical cells. These include, but are not limited to, the following:

- age (which alters the location of the squamocolumnar junction);

- hormonal status (which alters the location of the squamocolumnar junction);

- previous cervical surgery or trauma;

- parity;

- phase of the menstrual cycle ${ }^{10}$;

- sample taker; and

- the type of sampling instrument used.

There have been conflicting reports as to whether the experience of the person obtaining the sample influences smear adequacy. . $^{3,4}$ Our study shows that, under supervision, in- experienced third-year medical students obtain smears just as effectively as do more experienced gynecology residents.

This finding is consistent with the data reported by Taylor and co-workers. ${ }^{4}$ In the study by Boon and colleagues, ${ }^{3}$ the experience of the sample taker reflected a difference in sampling efficacy. This difference was minimized in that study by the use of the endocervical brush as compared with the swab. Because our two groups were equally effective in obtaining a satisfactory smear, the groups were combined for the second part of the study.

Although satisfactory Papanicolaou smears were obtained equally by residents and students, the overall disparate efficacy between the endocervical brush and the swab was apparent. The use of the endocervical brush resulted in a significantly higher percentage of satisfactory smears. The brush is more effective for several reasons. Its shape allows easier introduction into the endocervical canal. The brush does not absorb cells into its matrix as does the swab. ${ }^{1,7}$ Its bristles are more effective in capturing cells and cause less trauma to the cells during their transfer to a glass slide.

The next part of the study examined what portion of the smear (endocervical brush or 
swab versus ectocervical spatula) contributed to adequacy.

When these data were analyzed as to brushobtained versus swab-obtained endocervical smears, a distinct difference was apparent. The incidence of satisfactory smears on both endocervical and ectocervical specimens was much higher in the endocervical brush group (76\%) compared with the swab group $(40 \%)$.

In $9 \%$ of the smears, only the ectocervical specimen was satisfactory. This was true in $20 \%$ of the smears in which the endocervical specimen was obtained with a swab, whereas only $2 \%$ of brush-obtained endocervical specimens were unsatisfactory. Thus, the spatulaobtained specimen was more important in the case of smears obtained by using the swab.

\section{Conclusion}

Our study shows that properly instructed, inexperienced individuals can obtain a satisfactory Papanicolaou smear. The brush proved far more effective than the cotton-tip swab in obtaining satisfactory endocervical specimens. The spatula makes an important contribution to the Papanicolaou smear. This information implies that routine screening cervical cytology can be performed by a wide variety of healthcare personnel. The endocervical brush should replace the cotton-tip swab for obtaining the endocervical specimen and the spatula should be retained.

1. Kawaguchi K, Nogi M, Ohya M, et al: The value of the cytobrush for obtaining cells from the uterine cervix. Diagnostic Cytopathology 1987;3:262-267.

2. Trimbos JB, Arentz NPW: The efficiency of the cytobrush versus the cotton swab in the collection of endocervical cells in cervical smears. Acta Cytol 1986;30:261-263.

3. Boon ME, Alons-van Kordelaa: JJM, Rietveld-Scheffers PEM: Consequences of the introduction of combined spatula and cytobrush sampling for cervical cytology. Acta Cytol 1986;30:264270.

4. Taylor PT, Andersen WA, Barber SR, et al: The screening Papanicolaou smear: Contribution of the endocervical brush. Obstet Gynecol 1987;70:734-737.

5. Andersen WA, Frierson H, Barber SR, et al: Sensitivity and specificity of endocervical curettage and the endocervical brush for the evaluation of the endocervical canal. Am J Obstet Gynecol 1988;159:702-707.

6. Weitzman GA, Korhonen MO, Reeves KO, et al: Endocervical brush cytology: An alternative to endocervical curettage? $J R e$ prod Med 1988;33:677-683.

7. Dotters DJ, Carney CN, Droegemueller W: Nylon brush im- proves collection of cervical cytologic specimens. Am J Obstet Gynecol 1988;159:814-819.

8. Reissman SE: Comparison of two Papanicolaou smear techniques in a family practice setting. J Fam Prac 1988;26:525529 .

9. Woodman CJB, Yates M, Williams DR, et al: A randomized control trial of two cervical spatulas. $\mathrm{Br} J$ Obstet Gynaecol 1991;98:21-24.

10. Vooijs GP, van der Graaf Y, Elias AG: Cellular composition of cervical smears in relation to the day of the menstrual cycle and the method of contraception. Acta Cytol 1987;31:417-426.

11. Kivlahan C, Ingrom E: Papanicolaou smears without endocervical cells: Are they adequate? Acta Cytol 1986;30:258-260. 12. Koss LG: The Papanicolaou test for cervical cancer detection: A triumph and a tragedy. JAMA 1989;261:737-744. 